Jurnal Gizi dan Dietetik Indonesia (Indonesian Journal of Nutrition and Dietetics) Vol. 8, No. 2, 2020: 61-67

\section{The effect yellow passion fruit peel juice (Passiflora eduils f.flavicarpa deg) on LDL to HDL cholesterol ratio in type 2 diabetes mellitus patients as predictors of cardiovascular disease}

DOI : http://dx.doi.org/10.21927/ijnd.2020.8(2).61-67

\author{
Dhuha Itsnanisa Adi ${ }^{1}$ \\ ${ }^{1}$ Faculty of Public Health, University of Jember, Jalan Kalimantan No.37, Krajan Timur, Sumbersari, \\ Sumbersari, Jember, Jawa Timur \\ *Corresponding author: dhuha.itsnanisa@unej.ac.id
}

\begin{abstract}
ABSTRAK
Latar Belakang: Rasio LDL terhadap HDL menggambarkan profil kolesterol LDL dan HDL dalam darah dan merupakan salah satu komponen penting sebagai indikator risiko penyakit kardiovaskular. Kandungan serat yang tinggi terutama pektin (serat larut air) pada kulit markisa kuning dapat mencegah penyerapan karbohidrat, menurunkan absorpsi lemak dan kolesterol darah sehingga dapat mengontrol kadar lipid dalam darah.

Tujuan: Penelitian ini bertujuan menilai pengaruh jus kulit markisa kuning terhadap rasio kolesterol LDL:HDL pada pasien diabetes mellitus sebagai prediktor penyakit kardiovaskuler di wilayah kerja puskesmas Teppo Kabupaten Pinrang.

Metode: Jenis penelitian ini adalah quasi eksperimen dengan rancangan non-randomized pre-test dan post-test with control group. Cara pemilihan sampel dengan metode purposive sampling sebanyak 40 orang yang dibagi dalam 2 kelompok. Kelompok perlakuan diberikan jus kulit markisa kuning sebanyak $250 \mathrm{ml} / \mathrm{hari}$ dan edukasi selama 15 hari sedangkan kelompok kontrol hanya diberikan edukasi.

Hasil: Hasil penelitian ini menunjukkan bahwa rasio kolesterol LDL: HDL pada kelompok intervensi mengalami penurunan dengan rerata penurunan sebesar 0,56 sedangkan pada kelompok kontrol mengalami peningkatan dengan rerata peningkatan sebesar 0,25 . Secara statistik menunjukkan adanya perbedaan antara kelompok intervensi dan kelompok control $(p<0,05)$.

Kesimpulan: Dengan demikian terdapat perbedaan yang signifikan rerata selisih rasio kolesterol LDL:HDL antara kelompok intervensi dan kelompok kontrol setelah pemberian jus kulit markisa kuning pada penderita diabetes mellitus.
\end{abstract}

KATA KUNCI: kulit markisa kuning; rasio LDL:HDL; prediktor penyakit kardiovaskuler

\begin{abstract}
Background: The ratio of $L D L$ to HDL illustrates the profile of $L D L$ and $H D L$ cholesterol in the blood and it is one of the important components as an indicator of risk for cardiovascular disease. High fiber content, especially pectin (water-soluble fiber) on the skin of yellow passion fruit can prevent the absorption of carbohydrates, reduce the absorption of fat and blood cholesterol so that it can control blood lipid levels. Objectives: To assess the effect of fruit peel juice on $L D L$ to HDL cholesterol ratio in patients with diabetes mellitus as predictors of cardiovascular disease in the working area of Teppo Health Center, Pinrang Regency.

Methods: This study was a quasi-experimental design with a non-randomized pre-test and post-test with the control group. The method of selecting samples with a purposive sampling method of 40 people divided into 2 groups. The treatment group was given $250 \mathrm{ml}$ of yellow passion fruit peel juice/day and education for 15 days while the control group was given education only.

Results: The result showed that $L D L$ to HDL cholesterol ratio in the intervention group decreased about 0.56 while in contrast $L D L$ to $H D L$ cholesterol ratio in the control group increased about 0.25 and statistically, the change was the difference $(p>0.05)$. Conclussion: Thus there is a significant difference in the mean
\end{abstract}


LDL to HDL cholesterol ratio between the intervention group and the control group after administration of yellow passion fruit skin juice in people with diabetes mellitus.

KEYWORDS: Yellow passion fruit peel juice; LDL to HDL cholesterol ratio; predictor of cardiovascular disease

Article info:

Article submitted on February 21, 2020

Articles revised on April 8, 2020

Articles received on May 9, 2020

\section{INTRODUCTION}

Cardiovascular disease is the leading cause of death in the world. The World Health Organization (WHO) shows that in 2016 an estimated 17.9 million people died due to cardiovascular disease ( $31 \%$ of deaths in the world), where more than three-quarters of deaths due to cardiovascular disease occurred in low and the middle-income countries. Indonesia is one of the middle-income countries, cardiovascular disease causes death by $9.49 \%$ and $8.10 \%$ in 2009 and 2010 (1). One of the main risk factors for cardiovascular disease is dyslipidemia, a condition characterized by high total cholesterol concentration, LDL cholesterol (low-density lipoprotein) and triglycerides as well as low HDL cholesterol (high-density lipoprotein) concentration from the normal limit, where almost $50 \%$ of dyslipidemia often occurs at type 2 diabetes mellitus patients (2), this is associated with a greater risk of death due to cardiovascular disease $(3,5)$.

An increase in LDL cholesterol and a decrease in $\mathrm{HDL}$ cholesterol can increase the LDL to HDL cholesterol ratio. The LDL to HDL cholesterol ratio is the most accurate parameter in predicting cardiovascular disease. Respondents with a high LDL to HDL cholesterol ratio have a greater risk of cardiovascular disease (6). This caused by a large amount of plaque in heart blood vessels which is at high risk of rupture, increasing the risk of sudden cardiac death. A study conducted in Finland, on a follow-up analysis, adjusted for age, year of examination, body mass index, systolic blood pressure, smoking, alcohol consumption, physical activity, years of education, diabetes, previous myocardial infarction, family history of coronary heart disease, and serum high-sensitivity C-reactive protein, there was an approximately twofold increase in the risk of sudden cardiac death (SCD) compared with serum quintile of LDL to HDL cholesterol ratio $>4.22$ compared to a ratio of LDL to HDL cholesterol $\leq 2.30$ (7)

One way to manage dyslipidemia as a major risk factor for cardiovascular disease is through diet modification. A study conducted in Taiwan shows that diet is significantly related to the incidence of dyslipidemia (8), including fat intake and fiber intake. The intake of saturated fat can increase blood cholesterol levels, especially LDL and reduce HDL levels, which results in the continued process of atherosclerosis in blood vessels (9), so that it can cause coronary heart disease. While fiber intake can reduce the risk of diseases such as diabetes, dyslipidemia, obesity and, cardiovascular disease (10). Study Kutsiyah et al. (2013), showed that subjects who had high LDL cholesterol and high total cholesterol tended to have lower fiber intake compared to normal ones. Meanwhile, subjects who have low triglyceride levels tend to have higher fiber intake compared to subjects who have high triglyceride levels (11).

Each region has its peculiarities for the region, including food potential. South Sulawesi is famous for its passion fruit and there are several passion fruit factories that manage passion fruit into passion fruit syrup. Passion fruit contains high fiber, including the skin which represents almost half of the mass of fruit which turned out to have high fiber content. However, in the process of processing, so far the passion fruit skins are only leftover products that are 
not utilized, thrown away (12). For every 100 grams of yellow passion fruit peel, contains a total of 65.22 grams of fiber; 48.12 grams of water-insoluble fiber and 17.11 grams of water-soluble fiber (13). One kind of water-soluble fiber contained in the yellow passion fruit peel is pectin (12).

Several studies on the use of passion fruit peel have a positive effect on glucose levels and lipid profiles. Study by Barbalho et al in 2012, which examined the effects of yellow passion fruit peel juice in Wistar rats, the result was glucose $(p=0.00048)$, triglycerides $(p=0.00701)$ and total cholesterol levels $(p=0.0069)$ decreased in animals given passion fruit peel extract when compared with the control group (14). Similarly with a previous study, which is conducted by Barbalho et al (2011) also showed that the giving of yellow passion fruit juice significantly reduced blood glucose levels $(p=0.00)$, cholesterol $(p=0.0332)$, triglycerides $(p=0.0225)$ and LDL $(p=$ 0.01330 and increase levels of HDL (0.0244) in rats with mothers suffering from diabetes (15).

Another study by Ramos et al in 2007, in women aged 30-60 years showed a decrease in total cholesterol levels $(p=0.00000)$ and LDL $(p=0.01193)$ after giving of 30 grams passion fruit peel flour (16). While the study conducted by Janebro et al in 2008 , in patients with diabetes mellitus also showed a decrease in triacylglyceride and an increase in HDL but did not show a decrease in total cholesterol and LDL levels in patients after giving of 30 grams passion fruit peel flour (17). This study aims to asses the effect of yellow passion fruit peel juice on LDL: HDL cholesterol ratio in patients with type 2 diabetes mellitus as a predictor of cardiovascular disease.

\section{MATERIALS AND METHODS}

This study was conducted in the working area of Teppo Health Center and the Salo Health Center in Pinrang Regency. This study has received ethical approval from the Health Ethics Committee of Faculty of Medicine, University of Hasanuddin No. 1771/ H48.4.5.3.1/PP36-KOMETIK/2015. This study was a quasi-experimental design with a nonrandomized pre and post-test with the control group. The population in this study were all diabetes mellitus patients which was registered at Teppo Health Center and Salo Health Center in Pinrang District. The sample was selected by using a purposive sampling method consisting of 40 participants and divided into 2 groups: the treatment group (Teppo Health Center) and the control group ( Salo Health Center). Teppo Health Center and Salo Health Center are both located in the same Regency with the same consumption patterns before and after the intervention which shows no difference in respondents nutritional intake (energy, carbohydrates, fat, protein, fiber, cholesterol, saturated fatty acids, PUFAs and MUFA) between groups before and after the intervention $(P>0.05)$..

Yellow passion fruit peel juice in this study was originally from Malakaji-Gowa which was made from 40 grams of passion fruit peel albedo (already through proximate test, test of food fiber content, pectin and sugar content and organoleptic test by fellow researchers in a research team through preliminary studies) which mixed with 2.5 grams of low-calorie sugar and $200 \mathrm{ml}$ of water then blended until smooth then heated to boiling ( \pm 2 minutes). Yellow passion fruit peel juice is only given to the intervention sample group to see the effect of yellow passion fruit peel juice on LDL to HDL cholesterol ratio in people with diabetes mellitus. Data analysis was performed univariately for each variable to see a general description of distribution and frequency. The bivariate test was carried out to compare the ratio LDL to HDL cholesterol before and after giving intervention, which was analyzed by using paired t-test/Wilcoxon test while to compare the ratio LDL to HDL cholesterol between two groups was analyzed by independent t-test / Man Whitney. Furthermore, the results of data analysis were presented in tabular form accompanied by narration.

\section{RESULTS}

\section{Characteristics of Respondents}

Based on Table 1 showed that age and BMI before the intervention did not differ between the two groups because of the $p$ value $>0.05$. While for LDL to HDL cholesterol ratio showed differences between the two groups. 
Table 1. Characteristics of Respondents Between Groups Before Intervention

\begin{tabular}{lccc}
\hline \multirow{2}{*}{ Variable } & \multicolumn{2}{c}{ Group } & \\
\cline { 2 - 3 } & Intervention & Control & p-value \\
\cline { 2 - 3 } & Mean \pm SD & Mean \pm SD & \\
\hline Age & $50.10 \pm 8.01$ & $51.15 \pm 7.513$ & 0.671 \\
BMI & $23.57 \pm 3,28$ & $23.72 \pm 3.02$ & 0.705 \\
LDL:HDL & $3.05 \pm 1.06$ & $2,38 \pm 0.83$ & 0.032 \\
\hline
\end{tabular}

Change of LDL Cholesterol Ratio: HDL Before and After Intervention

Based on Table 2, it can be seen that before the intervention, the ratio of LDL: HDL cholesterol in the intervention group, respondents who included in the risk category before the intervention was $55 \%$ but after the intervention decreased to $35 \%$, whereas in the control group included in the category $25 \%$ risk but after the intervention increased to $35 \%$.

The Difference of LDL to HDL Cholesterol Ratio Before and After Intervention Between Group

Based on Table 3, it can be seen that the change of mean LDL to HDL cholesterol ratio in the intervention group decreased significantly from 3.05 to $2.49(p<0.05)$. Whereas in the control group, the mean LDL to HDL cholesterol ratio increased, ie from 2.38 to 2.63 but not statistically significant $(p>0.05)$, which means there was no difference in LDL to HDL cholesterol ratio before and after giving intervention.

\section{Mean Difference Intake}

Based on Table 4, it can be seen that mean of change for energy, carbohydrate, protein and fiber intake in both groups (intervention and control) before and after the intervention were decreased, but statistically, the decrease was not significant $(p>0.05)$. While the change of mean for fat intake in both groups, before and after the intervention was increased, but statistically not significant ( $p>0.05$ ).

The Difference in Difference Between LDL and HDL Levels Before and After Intervention

Based on Table 5, it can be seen that the change of mean difference LDL to HDL cholesterol ration between the intervention and control groups was statistically significant, so there were differences

Table 2. Change of LDL Cholesterol Ratio: HDL Before and After Intervention

\begin{tabular}{ccccccccc}
\hline \multirow{3}{*}{ Category of LDL: HDL } & \multicolumn{4}{c}{ Pre } & \multicolumn{4}{c}{ Post } \\
\cline { 2 - 9 } & \multicolumn{2}{c}{ Intervention } & \multicolumn{2}{c}{ Control } & \multicolumn{2}{c}{ Intervention } & \multicolumn{2}{c}{ Control } \\
\cline { 2 - 9 } & $\mathbf{N}$ & $\mathbf{N}$ & $\mathbf{0}$ & $\mathbf{n}$ & $\mathbf{\%}$ & $\mathbf{n}$ & $\mathbf{\%}$ \\
\hline Risky & 11 & 55 & 5 & 25 & 5 & 25 & 7 & 35 \\
Not risk & 9 & 45 & 15 & 75 & 15 & 75 & 13 & 65 \\
\hline
\end{tabular}

Table 3. The Difference of LDL to HDL Cholesterol Ratio Before and After Intervention Between Group

\begin{tabular}{|c|c|c|c|c|c|c|}
\hline \multicolumn{2}{|c|}{ Group of Intervention } & \multirow{3}{*}{ p-value } & \multicolumn{2}{|c|}{ Group of Control } & \multirow{3}{*}{ p-value } & \multirow{3}{*}{$\begin{array}{c}\text { Nilai } p \\
\text { (Between-group } \\
\text { after intervention) }\end{array}$} \\
\hline Pre & Post & & Pre & Post & & \\
\hline mean $\pm S D$ & mean士SD & & mean $\pm S D$ & mean士SD & & \\
\hline $3.05 \pm 1.06$ & $2.49 \pm 0.71$ & $0.04^{*}$ & $2.38 \pm 0.83$ & $2.63 \pm 0.83$ & 0.296 & 0.574 \\
\hline
\end{tabular}

Tabel 4 Mean Difference Intake Before and After Intervention

\begin{tabular}{|c|c|c|c|c|c|c|c|}
\hline \multirow{3}{*}{ Intake } & \multicolumn{2}{|c|}{ Intervention Group } & \multirow{3}{*}{$p$-value } & \multicolumn{2}{|c|}{ Control Group } & \multirow{3}{*}{$p$-value } & \multirow{3}{*}{$\begin{array}{c}\text { p-value } \\
\text { (between- } \\
\text { group after } \\
\text { intervention) }\end{array}$} \\
\hline & Pre & Post & & Pre & Post & & \\
\hline & mean $\pm S D$ & mean $\pm S D$ & & mean $\pm S D$ & mean $\pm S D$ & & \\
\hline Energy & $1297.33 \pm 116.82$ & $1296.75 \pm 66.93$ & 0.985 & $1259.49 \pm 126.22$ & $1248.57 \pm 91.52$ & 0.720 & 0.065 \\
\hline Carbohydrat (g) & $213.32 \pm 27.91$ & $204.345 \pm 14,46$ & 0.148 & $202.185 \pm 18.68$ & $196.42 \pm 22.60$ & 0.231 & 0.194 \\
\hline Fat (g) & $25.87 \pm .92$ & $29.64 \pm 7.39$ & 0.125 & $23.44 \pm 11.77$ & $27.91 \pm 12.83$ & 0.156 & 0.185 \\
\hline Protein (g) & $52.26 \pm 9.78$ & $49.57 \pm 7.99$ & 0.407 & $50.84 \pm 9.20$ & $49.08 \pm 4.97$ & 0.395 & 0.817 \\
\hline Fiber(g) & $6.756 \pm 4.33$ & $5.78 \pm 2.72$ & 0.747 & $5.98 \pm 3.13$ & $5.56 \pm 3.15$ & 0.546 & 0.543 \\
\hline
\end{tabular}


in the average difference in LDL to HDL cholesterol ratio between the intervention group and the control group.

Table 5 Difference in Difference Between LDL and HDL Levels Before and After Intervention

\begin{tabular}{ccc}
\hline \multicolumn{2}{c}{$\Delta$ mean } & \multirow{2}{*}{ Nilai $\mathrm{p}$} \\
\cline { 1 - 2 } Group Intervention & Group Control & \\
\hline$\downarrow 0.56 \pm 1.14$ & $\uparrow 0.25 \pm 1.07$ & 0.026 \\
\hline
\end{tabular}

\section{DISCUSSION}

This study showed that LDL to HDL cholesterol ratio levels in the intervention group that included in the risk category after giving $250 \mathrm{ml}$ of passion fruit peel juice, decreased from $55 \%$ to $25 \%$ whereas in the control group, LDL to HDL cholesterol ratio levels of respondents that included in the risk category experienced an increase from $45 \%$ to $75 \%$. The decrease in the number of respondents in the risk category in the intervention group and the increase in the number of respondents in the control group were caused by changes in HDL and LDL cholesterol levels of each respondent. This was also seen in the mean of LDL to HDL cholesterol ratio in the intervention group after giving $250 \mathrm{ml}$ of passion fruit peel juice that also decreased significantly from 3.05 to $2.49(p<0.05)$. This showed that there was a difference in the mean of LDL to HDL ratio levels before and after giving intervention. Whereas in the control group, the mean of LDL to HDL ratio levels was increased, i.e. from 2.38 to 2.63 but not statistically significant $(p>0.05)$, which means there was no difference in LDL to HDL cholesterol ratio levels before and after giving intervention.

The reduction LDL to HDL cholesterol ratio mean in the intervention group was caused by the effect of the content of water-soluble fiber that found in the yellow passion fruit peel, especially pectin. The study was conducted by Ramos et al (2007), in women aged 30-60 years who have cholesterol levels $\geq 200 \mathrm{mg} / \mathrm{dl}$, after giving passion fruit peel flour for 60 days showed a decrease in LDL $(p=0.01193)$ and total cholesterol $(p=0.00000)$. While the study conducted by Janebro et al (2008), by giving yellow passion fruit peel flour showed a decrease in triglycerides and a significant increase in HDL but did not show a decrease in the level of total cholesterol and LDL levels of diabetes mellitus patients (17). Another study conducted on hypercholesterolemic male white rats (Rattus novergicus) concluded that there were significant differences in LDL cholesterol levels before and after pectin giving. The dose of $180 \mathrm{mg}$ was the dose that had the most effective in reducing LDL cholesterol levels in these mice (18).

Yellow passion fruit peel juice which given in this study contained 12.64 grams of fiber and pectin (water-soluble fiber) 2.75 grams. Pectin forms a gellike substance in the stomach and gives a feeling of fullness and delay the absorption of carbohydrates. Besides that pectin is also able to hold water, form a thick gel, which can reduce total cholesterol, triglycerides and, LDL and increase HDL levels. This is possible because the presence of fiber can increase the excretion of cholesterol and bile salts in the stool. Dietary fiber can bind bile acids, thereby preventing its absorption from the intestine, while also increasing its excretion through feces, thus increasing the conversion of cholesterol from blood serum to bile acid. Increasing fiber consumption can reduce energy absorption by depleting the availability of dietary energy while maintaining other important nutrients (19). Besides, the consumption of fiber can also help to reduce the absorption of fat and blood cholesterol (9). Therefore, consumption of fiber can reduce the risk for diseases such as diabetes, dyslipidemia, obesity and CVD. The effect of fiber intake on lipid profile was also shown by the study of Kustiyah et al (2013), which showed that subjects who had high levels of LDL cholesterol and high total cholesterol tended to have lower fiber intake compared to normal ones. Meanwhile, subjects who have low triglyceride levels tend to have higher fiber intake compared to subjects who have high triglyceride levels (11).

Based on the results of the 24-hour food recall of respondents, it appears that the average fiber intake of respondents is far from the recommended 25-35 gr/day (20). Therefore, by giving yellow passion fruit peel juice containing 12.64 grams of crude fiber plus the respondent's average fiber intake which ranges from 5-6 grams, the respondent's fiber intake has not 
reached the recommended fiber diet (25-35 gr/day). However, if seen from the amount of pectin content contained in passion fruit peel juice given in this study that is $(2.75 \mathrm{gr})$, it has been able to affect on the lipid profile, as found in the results of this study, which is a significant difference in the difference in LDL to HDL cholesterol ratio between the intervention group and the control group after giving yellow passion fruit peel juice in people with diabetes mellitus. This is supported by a meta-analysis study by Brown et al (1999) which shows the effect of pectin intake on total serum concentrations and LDL cholesterol is 2-9 g per day (21).

\section{CONCLUSION AND RECOMMENDATION}

Yellow passion fruit peel has high fiber content, especially water-soluble fiber (pectin) which can increase HDL cholesterol levels and reduce LDL cholesterol levels in the blood, thereby reducing the LDL to HDL ratio levels. This study can be used as a basis for developing and continuing further research. Need further research with a larger sample size with a longer duration of administration of yellow passion fruit peel juice

\section{Acknowledgements}

The author would like to thank the Teppo Health Center and Salo Health Center in Pinrang Regency for the permission that was given to carry out this study and to all respondents who have participated in this study, as well as all parties who have helped until the research is completed.

\section{REFERENCES}

1. Data P, Informasi Kemenkes R. Gambaran Penyakit Tidak Menular di Rumah Sakit di Indonesia Tahun 2009 dan 2010. Buletin Jendela Data dan Informasi Kesehatan. 2012;2(2):1-14.

2. Feingold KR. Dyslipidemia in Diabetes. [Updated 2020 Aug 10]. In: Feingold KR, Anawalt B, Boyce $A$, et al., editors. Endotext [Internet]. South Dartmouth (MA): MDText.com, Inc.; 2000. Available from: https://www.ncbi.nlm.nih.gov/ books/NBK305900/
3. Sapkota LB, Thapa S. Pattern of Dyslipidemia in Type 2 Diabetic Patients attending Tertiary Care Centre of Nepal. EC Endocrinology and Metabolic Research. 2019;4:15-22.

4. Tagoe DNA, Amo-Kodieh P. Type 2 diabetes mellitus influences lipid profile of diabetic patients. Scholars Research Library Annals of Biological Research [internet]. 2013;4(6):88-92.

5. Chehade JM, Gladysz M, Mooradian AD. Dyslipidemia in Type 2 Diabetes: Prevalence, Pathophysiology, and Management. Drugs. 2013;73(4):327-39.

6. Agusti NI, Yacob T, Fridayenti F. Profil Rasio Koleterol LDL dan HDL pada Pasien Stroke di Bagian Saraf RSUD Arifin Achmad Provinsi Riau Periode Januari Sampai Desember 2012: Riau University; 2014.

7. Kunutsor SK, Zaccardi F, Karppi J, Kurl S, Laukkanen JA. Is high serum LDL/HDL cholesterol ratio an emerging risk factor for sudden cardiac death? Findings from the KIHD study. Journal of atherosclerosis and thrombosis. 2016:37184.

8. Lin LY, Hsu CY, Lee HA, Wang WH, Kurniawan $A L$, Chao JC. Dietary patterns in relation to components of dyslipidemia and fasting plasma glucose in adults with dyslipidemia and elevated fasting plasma glucose in Taiwan. Nutrients. 2019 Apr;11(4):845.

9. Almatsier S. Prinsip Dasar IImu Gizi: Gramedia Pustaka Utama; 2010.

10. Gropper SS, Smith JL. Advanced nutrition and human metabolism. Cengage Learning; 2012.

11. Kustiyah L, Widhianti MU, Dewi M. Hubungan Asupan Serat dengan Status Gizi dan Profil Lipid Darah Pada Orang Dewasa Dislipidemia. Jurnal Gizi dan Pangan. 2013;8(3).

12. Simmaky S, Jannaki G. Extraction And Characterization of Pectin From Yellow Passion Fruit (Passiflora edulis f.flavicarpa L) Endocarp Peel. SAITM Research Symposium on Engineering Advancements. 2014.

13. Da Silva JK, Cazarin CBB, Junior SB, Augusto F, Junior MRM. Passion fruit (Passiflora edulis) Peel Increases Colonic Production of Short-Chain Fatty Acids in Wistar rats. LWT-Food Science and Technology. 2014;59(2):1252-7. 
14. Barbalho SM, de Souza mdss, e Silva jcdp, Mendes CG, de Oliveira GA, Costa T, et al. Yellow Passion Fruit Rind (Passiflora edulis): An Industrial Waste or An Adjuvant in The Maintenance of Glycemia and Prevention of Dyslipidemia? Journal of Diabetes Research and Clinical Metabolism. 2012;1(1):5.

15. Barbalho SM, Damasceno DC, Spada APM, Lima iedr, Araújo AC, Guiguer EL, et al. Effects of Passiflora edulis on The Metabolic Profile of Diabetic Wistar Rat Offspring. Journal of Medicinal Food. 2011;14(12):1490-5.

16. Ramos AT, Cunha MAL, Sabaa-Srur AU, Pires VCF, Cardoso AA, Diniz mdf, et al. Use of Passiflora edulis $f$. Flavicarpa on Cholesterol Reduction. Revista Brasileira de Farmacognosia. 2007;17(4):592-7.

17. Janebro DI, Queiroz mdsrd, Ramos AT, SabaaSrur AU, Cunha mald, Diniz mdff. Effect of The Flour of The Yellow Passion Fruit Peel (Passiflora edulis f. Flavicarpa Deg.) In The Glycemic And Lipid Levels of Type 2 Diabetes
Patients. Revista Brasileira de Farmacognosia. 2008;18:724-32.

18. Nurman Z, Masrul M, Sastri S. Pengaruh pektin buah apel (Malus sylvestris mill) terhadap kadar LDL kolesterol pada tikus putih jantan (Rattus novergicus) hiperkolesterolemia. Jurnal Kesehatan Andalas. 2018 Feb 20;6(3):679-84.

19. Hall JE, Hall ME. Guyton and Hall textbook of medical physiology e-Book. Elsevier Health Sciences; 2020 Jun 13.

20. Kemenkes. Riset Kesehatan Dasar (Riskesdas) 2013. Jakarta: Badan Penelitian dan Pengembangan Kesehatan Departemen Kesehatan RI.2013.

21. EFSA. Scientific Opinion on the Substantiation of Health Claims related to Pectins and Reduction of Post-Prandial Glycaemic Responses (ID 786), Maintenance of normal Blood Cholesterol Concentrations (ID 818) and Increase in Satiety Leading to a Reduction in Energy Intake (ID 4692) pursuant to Article 13(1) of Regulation (EC) No 1924/2006. European Food Safety Authority. 2010;8(10):1-17. 